\title{
Distribution and habitat use intensity of the Neotropical Otter (Lontra longicaudis) in a Colombian hydroelectric dam
}

\author{
Lida Marcela Franco Pérez ${ }^{*}$, Pamela Andrea Hincapié-Usma², Carlos Andrés Restrepo ${ }^{3}$,
} Sergio A. Balaguera-Reina ${ }^{1} \&$ Giovany Guevara ${ }^{4 *}$

1. Facultad de Ciencias Naturales y Matemáticas, Programa de Biología Ambiental, Universidad de Ibagué. Ibagué, Colombia; lida.franco@unibague.edu.co; sergio.balaguera@unibague.edu.co

2. Departamento de Ciencias Biológicas, Facultad de Ciencias Exactas y Naturales, Universidad de Caldas, Manizales, Colombia; pamitohius8@gmail.com

3. Fundación Neotropica, Armenia, Colombia; carlosandres_restrepo@hotmail.com

4. Grupo de Investigación en Zoología (GIZ), Departamento de Biología, Facultad de Ciencias, Universidad del Tolima. Ibagué, Colombia; gguevara@ut.edu.co

* Correspondence

Received 21-X-2019. Corrected 07-VIII-2020. Accepted 31-VIII-2020.

\begin{abstract}
Introduction: The Neotropical Otter, Lontra longicaudis, is a semi-aquatic mammal that ranges from Mexico to Argentina inhabiting near-pristine watercourses, but also human-dominated aquatic and riparian landscapes. Objective: We assessed the distribution and habitat use frequency of L. longicaudis in La Miel I hydroelectric power dam and its influence area in the Department of Caldas, Colombia. Methods: We carried out diurnal surveys across standardized transects between 2014 and 2018 looking for records (sightings, faeces, tracks, and dens) that indicate the presence of the species. Each yearly survey was done during 12 consecutive days over three seasonal sampling periods assessing the upstream, reservoir, and downstream waterscape areas. Results: We sampled a total of $875 \mathrm{~km}$ in a five-year period across the three main waterscape areas (upstream $-103 \mathrm{~km}$, reservoir $-582 \mathrm{~km}$, and downstream $-190 \mathrm{~km}$ ) registering a total of 1496 records. Faeces were the most common record $(\sim 95 \%)$ across the whole study area followed by sightings, dens $(1.7 \%$ each), and tracks (1.3\%). Spatial distribution analyses suggest that $L$. longicaudis prefers dwelling upstream watercourses (hot spots areas; Gi Z-score $=4.46, \mathrm{p}<0.001$ ) and in a lesser extent, areas around the water reservoir (cold spot areas; Gi Z-score $=-2.69, p=0.007)$. Signs of otters were also recorded at downstream area, but these records were non-significant within the analysis (Gi Z-score $=-0.11, \mathrm{p}=0.48$ ), suggesting L. longicaudis uses this area opportunistically. Cluster and outlier analysis showed that even though L. longicaudis was commonly found upstream and in the reservoir area, only some specific sectors (Moro, La Miel and Tasajos rivers) had high (LMI Z-score $=5.63, \mathrm{p}=0.001)$ and low (LMI Z-score $=2.12, \mathrm{p}=0.001)$ clusters. Conclusions: The upstream waterscape area is key for the survival of $L$. longicaudis in this regulated system, likely providing enough shelter and food for the species to carry out living activities and have resident populations. In contrast, downstream areas require specific attention to understand in a better way the effects of caused by the dam on the species dynamics, also defining management strategies that avoid population fragmentation and movement reduction.
\end{abstract}

Key words: Conservation; distribution; hot spots; mustelids; tropical reservoirs.

Franco Pérez, L.M., Hincapié-Usma, P.A., Restrepo, C.A., Balaguera-Reina, S.A., \& Guevara, G. (2020). Distribution and habitat use intensity of the Neotropical Otter (Lontra longicaudis) in a Colombian hydroelectric dam. Revista de Biología Tropical, 68(Suppl. 2), S177-S189. 
By understanding the spatial ecology of a particular species, researchers can assess its distribution based on its biological requirements (Brown, Stevens, \& Kaufman, 1996). These attributes are especially important in species with conservation concerns such as otters, canids, crocodylians and other Neotropical predators (Hernández-Romero, Botello López, Hernández García, \& Espinoza Rodríguez, 2018), providing relevant information for the development of action plans and conservation strategies (Boitani \& Powell, 2012; BalagueraReina et al., 2016). Geostatistical approaches such as hot and cold spots (Getis-Ord Gi) and clusters and outliers (Anselin Local Moran I) analyses combined with environmental variables relevant for species, allow researchers to define and prioritize key areas based on the understanding of how species use space (Nelson \& Boots, 2008). This is important, especially in impacted or transformed areas, allowing the development of well-informed conservation and management planning.

The Neotropical Otter (Lontra longicaudis Olfers, 1818) is a semi-aquatic mammal species that ranges from Mexico to Argentina (including northeastern Brazil) and is currently categorized as "Near Threatened" by the IUCN Red List (Kruuk, 2006; Rheingantz, de Menezes, \& de Thoisy, 2014; Rheingantz et al., 2018). This species inhabits a large variety of climates and ecosystems including fast-flowing rivers, lakes, marshes, rocky seacoasts, mangroves, and wetlands (Kruuk, 2006; Almeida \& Ramos Pereira, 2017; Rheingantz, Santiago-Plata, \& Trinca, 2017; Gomez, Túnez, Fracassi, \& Cassini, 2014; Andrade, Arcoverde, \& Albernaz, 2019). However, despite its wide distribution, L. longicaudis has been poorly studied and a vast majority of information regarding its biology and natural history is still unknown (Larivière, 1999; Kruuk, 2006; Andrade-Ponce \& Angarita-Sierra, 2017; Rheingantz et al., 2018). This is also the case for Colombia, where despite the L. longicaudis widespread distribution [river networks in the Caribbean, Pacific, Andean, Amazonian, and Orinoco regions up to 3110 m.a.s.l. (Alberico,
Cadena, Hernández-Camacho, \& Muñoz-Saba, 2000, Trujillo et al., 2016, Andrade-Ponce \& Angarita-Sierra, 2017), the species still lack of some basic ecological information and it is considered of special interest for research and conservation assessments (González-Maya et al., 2011; Trujillo et al., 2016; Botero-Botero, Delgado, \& Gamboa, 2017; Camp, 2018; Pinillosa, Pérez-Torres, \& Botero-Botero, 2018).

Colombia has the third largest installed hydropower capacity in South America, producing a total of $11837 \mathrm{MW}$ per year (IHA, 2019). The construction of regulated river systems along the country has increased in the last 30 years, mainly due to the need to increase the national installed energy capacity (Bresney, 2016). However, little is known regarding the impact of these anthropogenic developments over wild population, especially cryptic species like the Neotropical Otter. Understanding these impacts are required for the development of technical-wise management planning (Quadros, 2012; Palmeirim, Peres, \& Rosas, 2014; Calaça \& de Melo, 2017; Restrepo, Botero-Botero, Puerta Parra, Franco Pérez, \& Guevara, 2018). We assessed the distribution and habitat use intensity of $L$. longicaudis in $\mathrm{La}$ Miel I hydroelectric power dam reservoir and its influence area (up and downstream) in the Department of Caldas, Colombia.

\section{MATERIALS AND METHODS}

Pre-sampling: In 2014, we visited La Miel I hydroelectric power dam headquarters to define areas, transects, sampling periods, and all the logistics in agreement with permits granted by the dam operator (ISAGEN). We surveyed the upstream, reservoir, and downstream waterscape areas evaluating the topography, accessibility, and navigability of water bodies, assessing restrictions and adjustments to be done to the standardized method defined for the study of otter's distribution (Reuther et al., 2000; Groenendijk et al., 2005). Based on these surveys, we defined 10 sites across three main waterscape areas: (1) upstream [La Miel River before Samaná bridge (LMR-SB), 
Tasajos River (TR), Manso River (MR), Moro River (MrR), San Luis River (SLR), Fraguas Stream (FS) and Santa Barbara Stream (SBS)], (2) reservoir [Amaní reservoir (AR)], and (3) downstream [La Miel River La Isla bridge (LMR-IB) and La Miel River La Palmera-San Miguel (LMR-SM)] to be assessed by boat and foot (Fig. 1). The former method was used in two of the 10 sites (AR and LMR-SM) due to topographic (mean slope $44^{\circ}$, slippery substrate) and navigability (deep waters) conditions, moving at slow speeds $(<10 \mathrm{~km} / \mathrm{h})$ close to the shoreline. The latter method was used in the remaining eight sites [LMR-SB, TR, MR, MrR, SLR, FS, SBS, and LMR-IB] due to navigability conditions (rocky-shallowed areas), following linear transects along both shorelines of streams and rivers in opposite directions.
Study area: La Miel I hydroelectric power dam is located between $05^{\circ} 33^{\prime} 38^{\prime \prime} \mathrm{N}$ and $74^{\circ} 53^{\prime} 12^{\prime \prime} \mathrm{W}$ to an elevation of 446 m.a.s.l. covering the municipalities of Norcasia, Samaná, Victoria, and La Dorada, Department of Caldas, Colombia. It is a gravity dam with a reservoir wall of $188 \mathrm{~m}$ high that can storage 571 million $\mathrm{m}^{3}$ water with a surface area of 1220 ha. This dam receives waters from $\mathrm{La}$ Miel and Moro rivers (contributing to $70 \%$ of the total input water), which are the main tributaries of the Magdalena River middle basin. The dam was built between 1997 and 2002, with the main purpose of hydroelectric power generation with an installed capacity of 396 MW and an annual generation of $1146 \mathrm{GWh}$. This area has a mean annual temperature of 27 ${ }^{\circ} \mathrm{C}$, average precipitation of $3500 \mathrm{~mm}$ per year,

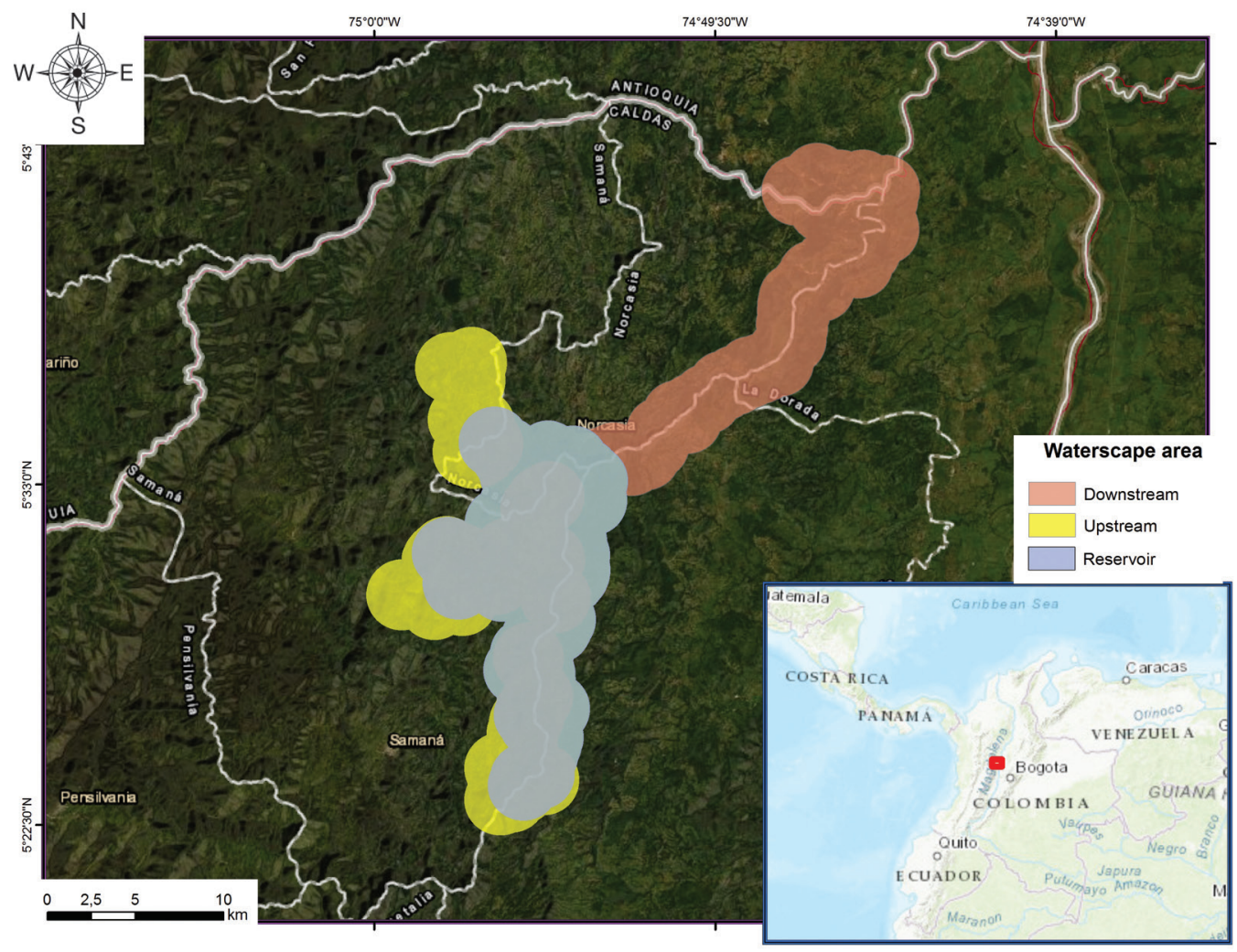

Fig. 1. Schematic map of La Miel I hydroelectric power dam and its influence area highlighting the three waterscapes areas assessed in the present study (upstream, reservoir, and downstream). 
and relative humidity between 60 and $100 \%$ (Rojas-Morales, Marín-Martínez, \& ZuluagaIsaza, 2018). This region corresponds to the socalled humid tropical or equatorial zonobiome of the Colombian Andes central range formed by hilly landscapes with steep slopes and areas dominated by pastures and pastures in early regeneration ( $0-2$ years) with some isolated patches of riparian, primary and secondary forest (mainly on the headwaters; Rodríguez, Armenteras, Morales, \& Romero, 2006).

Surveys and data analyses: We carried out diurnal surveys across standardized transects between 2014 and 2018 looking for records (sightings, faeces, tracks, and dens) that indicate L. longicaudis presence. Each year, surveys were done within 12 consecutive days over three seasonal sampling periods [February - March (low rainy season), July (dry season), and November (high rainy season); 36 sampling days per year] assessing the upstream, reservoir, and downstream waterscape areas (Table 1). We attributed a site as positive when we found at least one otter record and as negative otherwise (Riesco et al., 2020). Each positive record was georeferenced (Garmin 62sc) and variables such as the number of records (individuals, faeces, tracks, or dens), date, riverscape area (upstream, reservoir, downstream), and marking substrate (trunk, rock or latrine) were registered. In all cases, four expert members ( 3 biologists and 1 local fisherman) participated in the field expeditions; paired members were ubicated oppositely within the boat to have a full vision of the prospected areas during the travels. When surveying by foot, the same team divided forces, two per side of the river, following fixed linear transects throughout the river shore.

Data were analyzed descriptively, classifying them by record type (sighting, faeces, track or dens), estimating the frequency of use by sites, areas, and years via contingency tables (Pearson's $\chi^{2}$ ). We also performed two geostatistical analyses, the optimized hot spot analysis (Getis-Ord Gi) and the cluster and outlier (Anselin local Moran's I) analysis via ArcGIS 10.7 (ESRI, 2018), to define statistically significant areas $(\mathrm{p}<0.05)$ with high and low record aggregations (hot and cold spots) within a threshold $(5 \mathrm{~km})$, as well as, specific sites with high and low spatial autocorrelation (high - high and low - low clusters).

\section{RESULTS}

We sampled a total of $875 \mathrm{~km}$ in a fiveyear span across the three main waterscape areas (upstream $-103 \mathrm{~km}$, reservoir $-582 \mathrm{~km}$, and downstream $-190 \mathrm{~km}$ ). Transects by foot and by boat were in average $2.9 \pm 1 \mathrm{~km}$ and $75.9 \pm 45.4 \mathrm{~km}$, respectively across areas and years (Table 2). These variations in transect lengths across space and time were mainly

TABLE 1

Sampling sites by riverscape areas at La Miel I hydroelectric power dam (Caldas, Colombia), highlighting the transect length and the sampling method used

\begin{tabular}{llcc}
\multicolumn{1}{c}{ Riverscape area } & \multicolumn{1}{c}{ Sampling site } & Transect length $(\mathrm{km})$ & Sampling method \\
Upstream & La Miel River before dam Samaná bridge (LMR=SB). & $2.5 \pm 0.7$ & By foot \\
& Tasajos River (TR) & $2.7 \pm 0.6$ & By foot \\
& Manso River (MR) & $5.0 \pm 0.0$ & By foot \\
& Fraguas stream (FS) & $2.6 \pm 1.0$ & By foot \\
& Santa Bárbara stream (SBS) & $2.7 \pm 1.0$ & By foot \\
& Moro River (MrR) & $2.5 \pm 0.8$ & By foot \\
Reservoir & San Luis River (SLR) & $2.7 \pm 0.8$ & By foot \\
Downstream & Amaní reservoir (AR) & $116.4 \pm 23.5$ & By boat \\
& La Miel River Muro- La Isla bridge (LMR-IB) & $2.6 \pm 0.5$ & By foot \\
& La Miel River La Palmera-San Miguel (LMR-SM) & $35.5 \pm 1.6$ & By boat \\
\hline
\end{tabular}




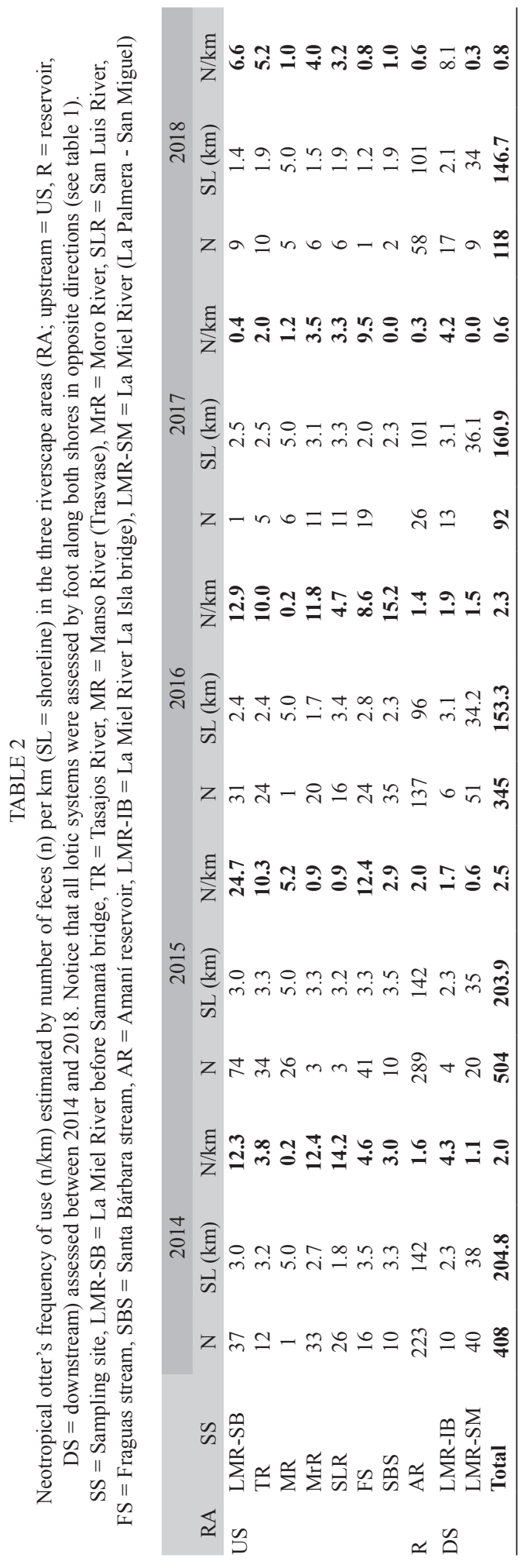

due to dam water oscillations ( $\sim 30 \mathrm{~m}$ between the highest and lowest water mark) caused by precipitation (weather season) and the mechanical water release and storage depending on the hydroelectrical power requirements, which influenced walkable shorelines availability.

We registered a total of 1496 records from which faeces had the highest number (95.4 \%, N = 1 467), followed by sightings, dens ( $1.7 \%, \mathrm{~N}=26$ and 25 , respectively), and tracks $(1.3 \%, \mathrm{~N}=19)$. The number of records varied across sampling years, with the highest presence occurring during 2015 (reservoir = $163>$ upstream $=116>$ downstream $=14$ ), followed by 2014 (reservoir $=121>$ upstream $=107>$ downstream $=29), 2016$ (upstream $=$ $93>$ reservoir $=64>$ downstream $=26), 2017$ (upstream $=44>$ reservoir $=21>$ downstream $=19$ ), and 2018 (reservoir $=32>$ upstream $=$ $29>$ downstream $=16$ ). However, considering only faeces (the most abundant record) standardized by $\mathrm{km}$, the highest frequency of use was reported upstream in LMR-SB (29.6 faeces $/ \mathrm{km})$, followed by FS (20.5 faeces $/ \mathrm{km})$, TR (13.6 faeces $/ \mathrm{km})$, and MR (10.4 faeces $/ \mathrm{km}$ ) in 2015. In contrast, we did not register any records across SBS (upstream) and LMR-SM (downstream) in 2018. Likewise, the downstream area (LMR-IB and LMR-SM) showed the lowest frequency of use during the whole study (2014-2018; Table 2). We found significant differences by riverscape areas, sampling periods, and years with respect substrate preference (rocks vs trunks) being the former preferred over the latter in all cases (rock $\mathrm{N}=813$ vs. trunk $\mathrm{N}=501$; Pearson's $\chi^{2}=988.10$ and 300.60 , d.f. $=144$ and 108, $<<0.001$; Fig. 2).

We found the highest number of sightings in the downstream waterscape area at LMR$\mathrm{SM}(\mathrm{N}=11)$ followed by the AR $(\mathrm{N}=2)$. Conversely, FS $(\mathrm{N}=2)$ had the highest number of sightings upstream followed by LMR-SB and SLR $(\mathrm{N}=1)$. The number of sightings was also higher in 2015 with 10 observations in the reservoir. Finally, we did not record any sighting across the studied area in 2014. Regarding dens, we registered a total of 25 over the study period with the highest records 


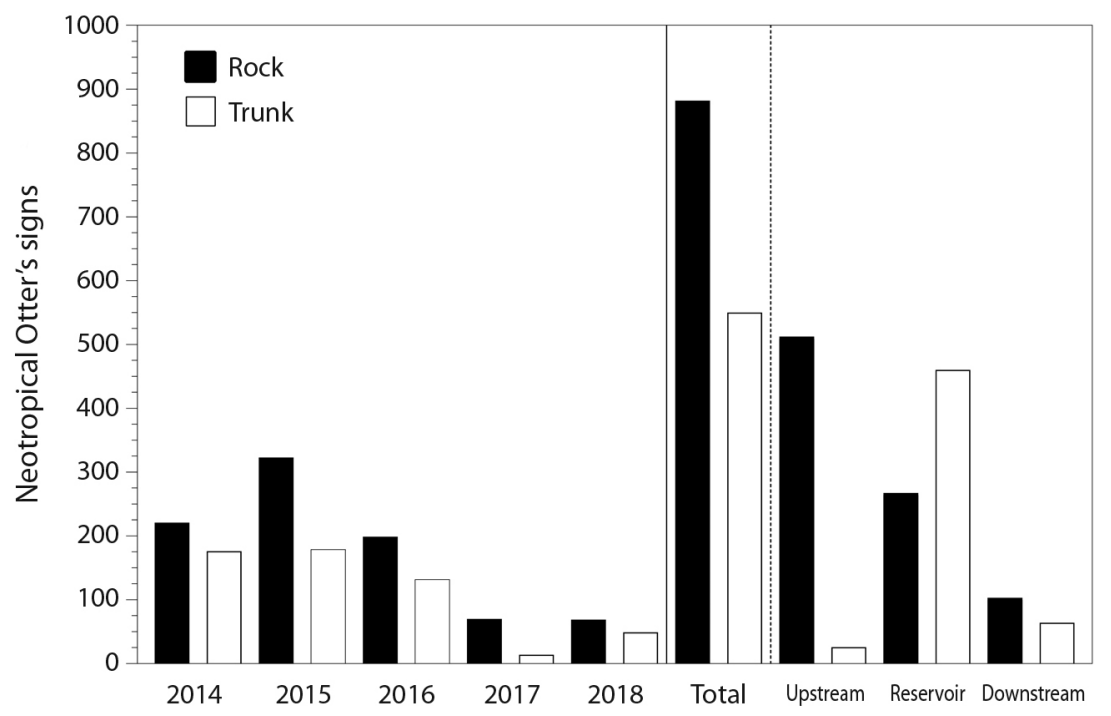

Fig. 2. Neotropical Otter records (faeces, dens, and tracks) per year registered at La Miel I hydroelectric power dam (Caldas, Colombia), highlighting signs recorded in rocks (black bars) and trunks (white bars) and totalized by riverscape area.

found upstream in LMR-SB $(\mathrm{N}=4)$ and SBS $(\mathrm{N}=2)$ in 2014, AR $(\mathrm{N}=2)$ in 2015, LMR-SM $(\mathrm{N}=3)$ and $\mathrm{AR}(\mathrm{N}=1)$ in 2016, and $\mathrm{FS}(\mathrm{N}=$ 1) and LMR-SM $(\mathrm{N}=2)$ in 2017. The average dimensions of dens were $2.7 \pm 2.7 \mathrm{~m}$ high and $2.9 \pm 2.9 \mathrm{~m}$ wide with a horizontal distance to the water line of $2.6 \pm 1.2 \mathrm{~m}$, a canopy cover of $46 \pm 27.7 \%$ and a slope of $41 \pm 15.5^{\circ}$.

An initial exploratory analysis showed a large agglomeration of data at the upstream and reservoir waterscape areas compared with the downstream waterscape area across all years. From these, 2017 had the highest number of sightings and the lowest number of faeces recorded comparatively speaking with other years (Fig. 3). Geostatistical analyses corroborate this exploratory analysis defining the upstream waterscape area as a hot spot (Gi $\mathrm{Z}$-score $=4.46, \mathrm{p}<0.001)$ and the reservoir as a cold spot (Gi Z-score $=-2.69, \mathrm{p}=0.01$; Fig. 3 ). This means the upstream area had a higher number of records with a homogeneous variance which may indicate a constant presence of the species and a higher number of individuals inhabiting the area. This also is true for the reservoir (i.e., a cold spot), but with a much smaller number of records, indicating a constant presence of $L$. longicaudis with a lower number of individuals. Finally, even though downstream waterscape areas had a variety of records (faeces, tracks, and dens) and the largest number of sightings across the study, it was not statistically significant $(\mathrm{Gi} \mathrm{Z}$-score $=$ $-0.11, p=0.48$; Fig. 4), implying that we could not identify patterns in the number of records spatially registered, which can be explained by the use of this area as a passing by rather than a residential area.

A more in-depth spatial analysis (Anselin Local Moran's I cluster and outlier analysis) showed higher spatial autocorrelation with the high number of records in the reservoir AR (high - high cluster; LMi Z-score $=5.63, p=$ 0.001 ) and high spatial autocorrelation with a low number of records upstream in LMR-SB and TR (low - low cluster; LMi Z-score = $2.12, p=0.001)$. This means that even though the upstream waterscape area was defined as a hot spot area, it is not all but some sites such as LMR-SB and MR more likely to host resident populations of the Neotropical Otter. Interestingly, this analysis recovered a low - low 


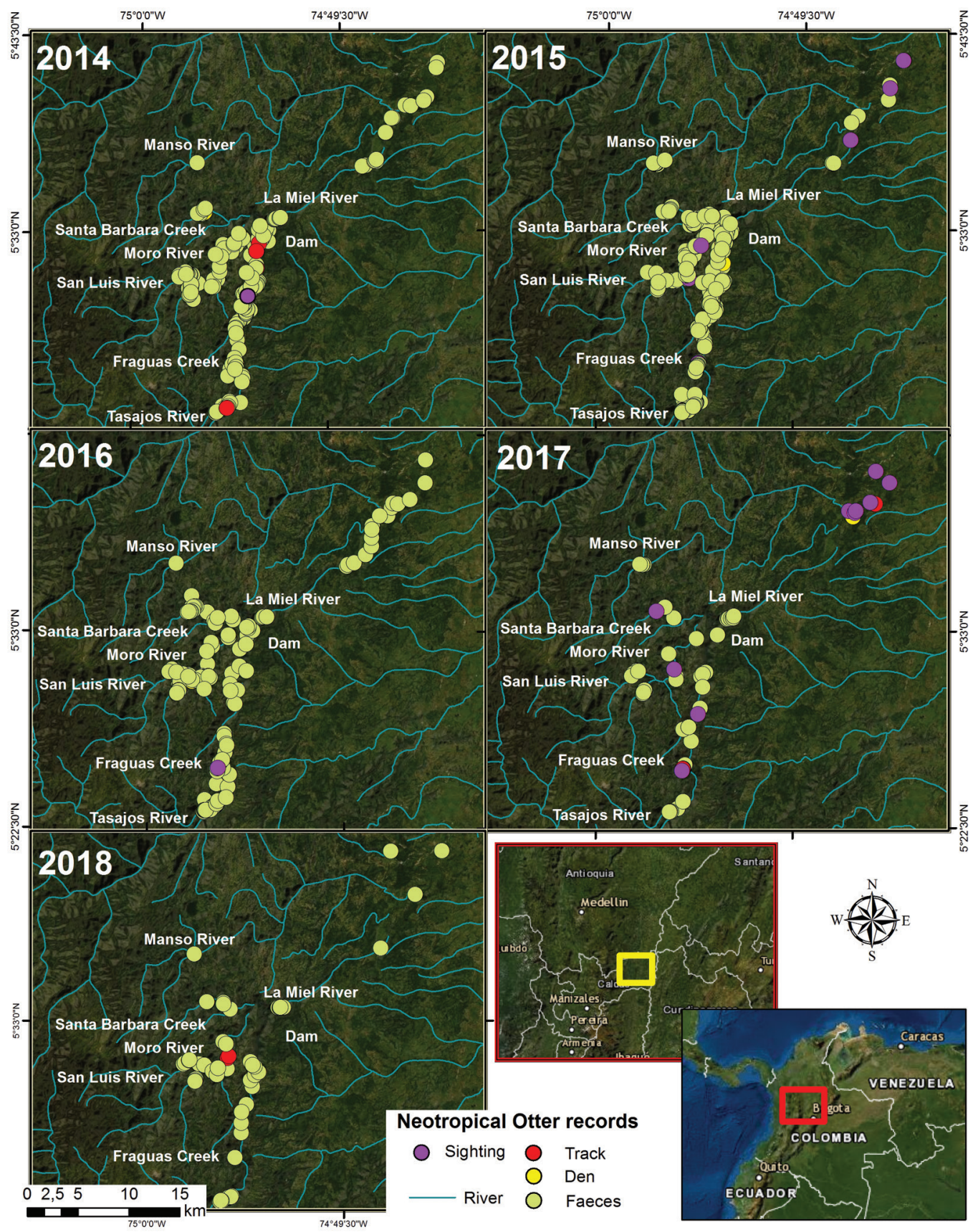

Fig. 3. Distribution of Lontra longicaudis in La Miel I hydroelectric power dam and its influence area (Caldas, Colombia). Notice the variation in the number and distribution of records across years. 


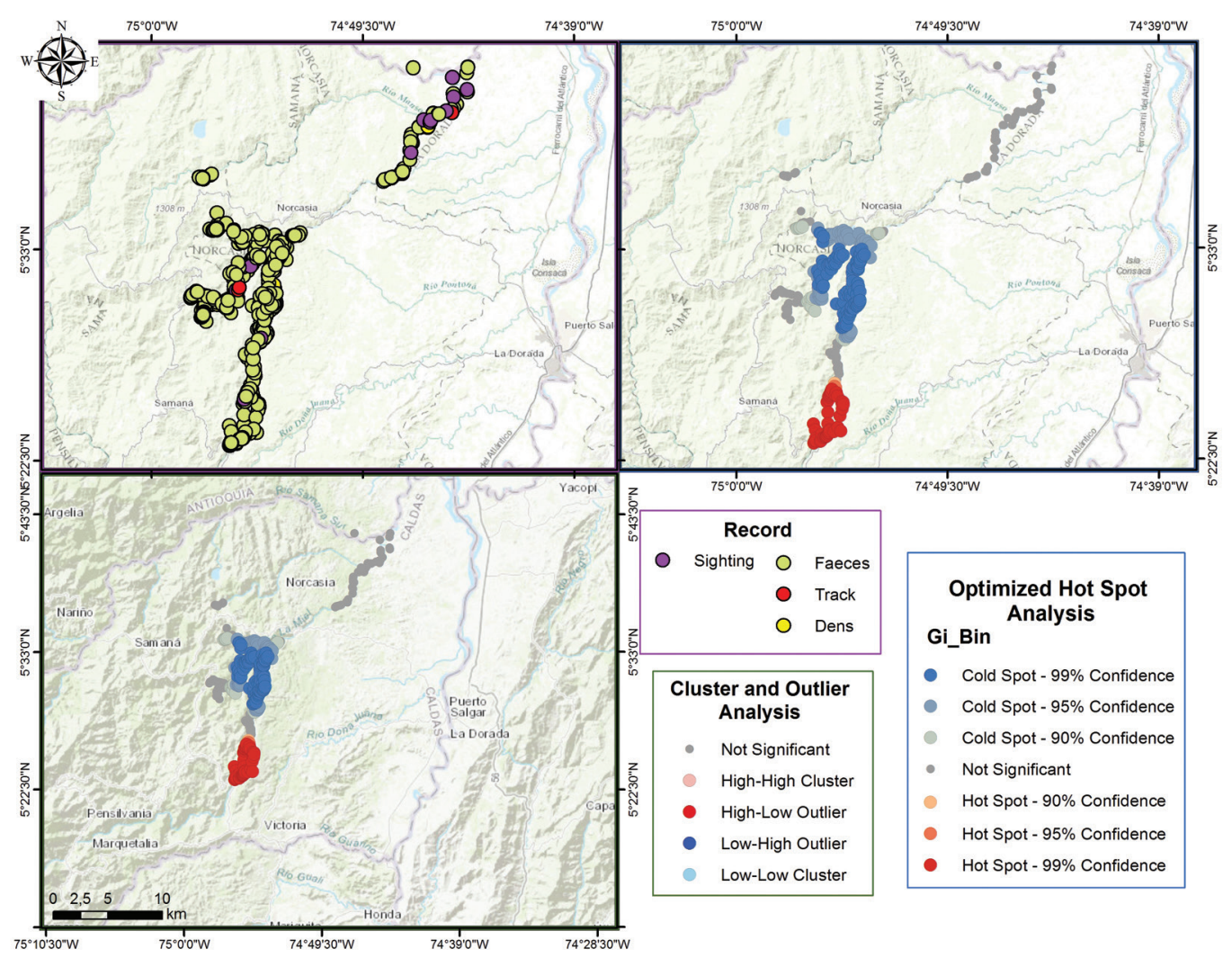

Fig. 4. Optimized hot spot analysis and cluster and outlier analysis of the Neotropical Otter records registered at the La Miel I hydroelectric power dam (Caldas, Colombia), highlighting statistically significant areas with high number of records/low variation (hot spots) and highly spatially autocorrelated (high - high cluster), low number of records/low variation (cold spots) and highly spatially autocorrelated (low - low cluster).

cluster downstream (LMR-SM) that the hot spot analysis could not identify (Fig. 4).

\section{DISCUSSION}

This is one of the first studies in Colombia that sheds some light on the spatial ecology, habitat, and intensity of use of the Neotropical Otter in an anthropogenically regulated system. Unfortunately, there are no available data regarding $L$. longicaudis ecological aspects in La Miel River basin before, during, or after damming that allow us to compare our results with. The only available data include anecdotal records and information from local fishermen across the river (Castaño \& Corrales, 2010; Restrepo et al., 2018). Thus, we presented the first technically driven information regarding
L. longicaudis collected La Miel I hydroelectric power dam and influence areas after 12-years of commercial operation.

We found that $L$. longicaudis preferred the upstream riverscape area based on a larger number of faeces and dens found, allowing us to identify this area as a hot spot (Fig. 4). This is likely due to the presence of habitat characteristics such as a rocky bed and forest coverage provided by riparian vegetation, which positively influences the species presence providing protection and shelter above water level to ensure cubs survival avoiding flooding and predators (Santos \& Reis, 2012; Rheingantz et al., 2017; Rheingantz et al., 2018), positive influencing the establishment of permanent otter populations. Downstream riverscape areas (LMR-SB and LMR-IB) had 
the lowest frequency of positive records but also one of the highest number of sightings and dens recorded, which might be related to mobility in response to species requirements such as food availability and refuge. However, special attention should be paid to records found in this area since the downstream waterscape has a high degree of anthropogenic pressure, which can likely impact the reproductive role of the species due to den availability and riparian habitat are essential for the survival of Neotropical Otters (Trujillo et al., 2016).

The low intensity of use (frequency of faeces $/ \mathrm{km}$ ) registered in the reservoir (AR) could be derived from topographic and bathymetric features such as water depth, the width of the water body, flooding oscillation $(\sim 30 \mathrm{~m}$ between the highest and lowest water peak) and shoreline and rocks availability (Foster-Turley, Macdonald, \& Mason, 1990; López-Casas, Jiménez-Segura, \& Pérez-Gallego, 2014). It has been registered that $L$. longicaudis tends to prefer shallow over deep water bodies due mainly to depth issues, reducing otter's fishing capacity (hunting efficiency) and prey availability (Neotropical Otters prefer prey with benthic habits; Foster-Turley et al., 1990, Somers \& Nel, 2004; Kruuk, 2006; Pedroso, Marques, \& Santos-Reis, 2014; Rheingantz et al., 2017), implying that systems as the Amaní reservoir (AR) are less suitable for Neotropical Otters than upstream and downstream waterscape areas.

Our analyses showed a selectivity pattern of use regarding the space across the study area likely influenced by no measured variables such as food availability, anthropogenic disturbance, and habitat conservation. Both the optimized hot spot analysis and the cluster and outlier analysis showed a more constant presence in higher numbers of Neotropical Otters in upstream areas such as LMR-SB, MR, FS and TR (hot spots and high - high cluster areas). In contrast, areas such as the reservoir (AR, cold spot) and downstream (LMR-SM; low - low cluster) had a constant presence of Neotropical Otters, but with a comparatively lower number of individuals even though the drastic flooding oscillation ( $\sim 30 \mathrm{~m}$ between the highest and lowest water peak) in the reservoir.

We could not find any statistically significant hot-cold spots downstream even though the great variety of records (faeces, tracks, and dens) and the highest number of sightings recorded in the area. However, we did identify a low - low cluster site (LMR-SM), which was highly related to the sector where dens were found. This is important to highlight because we do not know how changes in the river dynamic have impacted Neotropical Otter populations in this area. Unfortunately, no data regarding Neotropical Otter populations were collected prior to the dam's construction, so we cannot confidently say whether the low number of records reported downstream derived as an effect of the change in the water dynamic (lotic-to-lentic transition). Molecular approaches using codominant markers such as microsatellites and SNPs could bring information regarding gene flow and $L$. longicaudis population genetic structure that help to quantify this effect, which should be a priority to define management and conservation strategies.

Faeces counting has been a traditional non-invasive method used in numerous investigations because they are easily detected in the natural environment (Kasper, Bastazini, Salvi, \& Grillo, 2008; Rheingantz et al., 2011; Franco et al., 2013; Biffi \& Williams, 2017; Grajales-García et al., 2019). Faeces are generally deposited in conspicuous places along the shore of water bodies and can be clearly differentiated from those dropped by other carnivores (Delibes-Mateos, Díaz-Ruiz, Caro, \& Ferreras, 2014; Juarez-Sanchez, Blake, \& Hellgren, 2019). However, the detection probability of faeces decreases in prolonged rains periods since they can be easily rinsedoff (Medina-Vogel \& González-Lagos, 2008; Delibes-Mateos et al. 2014). Across our fiveyear study, we had high precipitation values in the last two years influenced by the "La Niña" phenomenon, which likely influenced the number of faeces recovered in our study. This implies the low numbers recorded in 2017 and 2018 could not derive from a reduction 
in the number of individuals present in the study area but rather a sampling bias caused by high precipitation levels.

Riversides areas such as LMR-SM are exposed to greater anthropogenic pressure due to livestock and agricultural activities. However, based on our findings, these areas are still used by L. longicaudis, corroborating what has been reported in the literature regarding Neotropical Otters tolerating certain degrees of disturbance (Kruuk, 2006; Navarro-Picado et al., 2017; Rheingantz et al., 2017; Rheingantz et al., 2018). Similarly, the LMR-IB is another site highly impacted by river flow change, having a low flow rate that increases slightly during the rainy season. This variable could have a long-term direct impact upon food availability for the Neotropical Otter, which could permanently influence the establishment of the species since it does not meet the optimal conditions and resources necessary for its survival.

Anthropogenic activities such as the construction of hydroelectric dams can significantly affect Neotropical Otter populations also generating drastic reductions in prey availability and local diversity due to habitat modification and physicochemical changes of water (Santos \& Reis, 2012; Palmeirim et al., 2014; Pedroso et al., 2014; Calaça, Faedo, \& de Melo, 2015; Rheingantz et al., 2018; CostaBraga, Rossi, \& Srbek-Araujo, 2019). Therefore, long-term monitoring is required to design sound conservation measures that can reduce impacts derived of these megaprojects, protecting the biodiversity as well as ecosystem functions (see Bresney, 2016; Angarita et al., 2018; IHA, 2019).

Ethical statement: Authors declare that they all agree with this publication and made significant contributions; that there is no conflict of interest of any kind; and that they followed all pertinent ethical and legal procedures and requirements. All financial sources are fully and clearly stated in the acknowledgements section. A signed document has been filed in the journal archives.

\section{ACKNOWLEDGEMENTS}

This study was financially supported by the research and graduate departments of the University of Caldas and ISAGEN (Agreement 47/623 and 33/45). We thank Juan Camilo Puerta Parra, Carlos Augusto Gil Henao and local fishermen from La Miel River for their logistic and fieldwork support as well as Dr. Beatriz Toro for the continuous supervision of the present study. We finally thank Brandon Gross, three anonymous reviewers, and handling editors of the special issue for the improvements proposed during the reviewing process.

\section{RESUMEN}

Distribución e intensidad de uso del hábitat de la nutria neotropical (Lontra longicaudis Olfers, 1818) en una represa hidroeléctrica colombiana. Introducción: La nutria neotropical Lontra longicaudis, es un mamífero semiacuático que se distribuye desde México hasta Argentina; habita en paisajes acuáticos y ribereños prístinos, pero también hábitats dominados por el hombre. Objetivo: Se evaluó la distribución e intensidad de uso del hábitat de L. longicaudis en la hidroeléctrica La Miel I y su área de influencia en el Departamento de Caldas, Colombia. Métodos: Se realizaron transectos diurnos estandarizados entre 2014 y 2018 en busca de registros (avistamientos, heces, huellas y madrigueras) que indicaban la presencia de la especie. Cada muestreo anual se realizó durante 12 días consecutivos en tres períodos de muestreo estacional (36 días), evaluando las áreas aguas arriba, el embalse y aguas abajo de la presa. Resultados: Se muestreó un total de $875 \mathrm{~km}$ a través de las tres áreas principales con un total de 1496 rastros. Las heces fueron el registro más común $(\sim 95 \%)$ en toda el área de estudio, seguido de avistamientos, madrigueras (1.7\% cada una), y huellas (1.3\%). Los análisis de distribución espacial sugieren que L. longicaudis prefiere los afluentes aguas arriba (áreas de puntos calientes; Gi Z-score $=4.46, \mathrm{p}<0.001$ ) y, en menor medida, las zonas alrededor del embalse (áreas de puntos fríos; Gi Z-score $=-2.69, \mathrm{p}=0.007$ ). El área aguas abajo también mostró presencia de nutrias; sin embargo, esos registros no fueron significativos dentro del análisis (Gi $\mathrm{Z}$-score $=-0.11, \mathrm{p}=0.48$ ), sugiriendo que $L$. longicaudis usa esta área esporádicamente. El análisis de conglomerados y datos atípicos mostró que, aunque L. longicaudis se encuentra comúnmente aguas arriba y en el área del embalse, solo algunos sectores específicos (ríos Moro, La Miel y Tasajos) tienen valores altos (LMI Z-score $=5.63$, $\mathrm{p}=0.001)$ y bajos (LMI Z-score $=2.12, \mathrm{p}=0.001)$ de conglomerados. Conclusiones: El paisaje y las características hidrológicas aguas arriba son claves para la supervivencia 
de la nutria neotropical en este sistema regulado, probablemente aportando suficiente refugio y alimento para que la especie lleve a cabo sus actividades vitales, permitiéndole tener poblaciones residentes. Se debe enfocar la atención en la zona aguas abajo para comprender el efecto de la presa en la dinámica de la especie, definiendo estrategias de manejo que eviten la fragmentación de la población y la reducción de los movimientos.

Palabras clave: Conservación; distribución; puntos calientes; mustélidos; embalses tropicales.

\section{REFERENCES}

Alberico, M., Cadena, A., Hernández-Camacho, J., \& Muñoz-Saba, Y. (2000). Mamíferos (Synapsida: Theria) de Colombia. Biota Colombiana, 1(1), 43-75. Retrieved from https://www.redalyc.org/ pdf/491/49110103.pdf

Almeida, L. R. d., \& Ramos Pereira, M. J. (2017). Ecology and biogeography of the Neotropical otter Lontra longicaudis: existing knowledge and open questions. Mammal Research, 62(4), 313-321. doi:10.1007/ s13364-017-0333-1

Andrade, A. M., Arcoverde, D. L., \& Albernaz, A. L. (2019). Relationship of Neotropical otter vestiges with environmental and anthropogenic factors. Acta Amazonica, 49(3), 183-192. doi:10.1590/1809-4392201801122

Andrade-Ponce, G. P., \& Angarita-Sierra, T. (2017). Notable altitudinal range expansion of Lontra longicaudis (Carnivora: Mustelidae) in Colombian Paramos. Therya, 8(1), 75-78. doi:10.12933/therya-17-429

Angarita, H., Wickel, A. J., Sieber, J., Chavarro, J., Maldonado-Ocampo, J. A., Herrera-R, G. A., . . Purkey, D. (2018). Basin-scale impacts of hydropower development on the Mompós Depression wetlands, Colombia. Hydrology and Earth System Sciences, 22(5), 2839-2865. doi:10.5194/hess-22-2839-2018

Balaguera-Reina, S. A., Venegas-Anaya, M., Sánchez, A., Arbelaez, I., Lessios, H. A., \& Densmore III, L. D. (2016). Spatial Ecology of the American Crocodile in a Tropical Pacific Island in Central America. PLOS ONE, 11(6), e0157152. doi:10.1371/journal. pone. 0157152

Biffi, D., \& Williams, D. A. (2017). Use of non-invasive techniques to determine population size of the marine otter in two regions of Peru. Mammalian Biology, 84, 12-19. doi:10.1016/j.mambio.2016.12.006

Boitani, L., \& Powell, R. A. (2012). Carnivore Ecology and Conservation: A Handbook of Techniques. Oxford, U. K.: Oxford University Press.

Botero-Botero, A., Delgado, P., \& Gamboa, R. (2017). Distribución, abundancia y hábitat de la nutria de río
Neotropical (Lontra longicaudis) en la cuenca del río Guaroco, Alto Magdalena, Colombia. Revista Biodiversidad Neotropical, 7(4), 243-252. doi:10.18636/ bioneotropical.v7i4.627

Bresney, S. (2016). Tradeoffs between hydropower generation and environmental impacts in the Alto Magdalena River basin. (Master of Science). Tufts University, Retrieved from https://dl.tufts.edu/concern/pdfs/0k225p12f Available from Institution Tufts Digital Library database.

Brown, J. H., Stevens, G. C., \& Kaufman, D. M. (1996). The Geographic Range: Size, Shape, Boundaries, and Internal Structure. Annual Review of Ecology and Systematics, 27(1), 597-623. doi:10.1146/annurev. ecolsys.27.1.597

Calaça, A. M., \& de Melo, F. R. (2017). Reestablishment of giant otters in habitats altered by the filling of the Teles Pires hydroelectric aam in the Amazonia. IUCN Otter Specialist Group Bulletin, 34(2), 73-78. Retrieved from https://www.iucnosgbull.org/Volume34/ Calaca_Melo_2017.pdf

Calaça, A. M., Faedo, O. J., \& de Melo, F. R. (2015). Hydroelectric Dams: The First Responses from Giant Otters to a Changing Environment. IUCN Otter Specialist Group Bulletin, 32(1), 48-58. Retrieved from https:/www.iucnosgbull.org/Volume32/Calaca et al 2015.pdf

Camp, V. L. (2018). A Bibliography on the neotropical river otter Lontra longicaudis. IUCN Otter Specialist Group Bulletin, 35(B), 3-22. Retrieved from https:// www.iucnosgbull.org/Volume35B/Camp Neotropical 2018.pdf

Castaño, J. H., \& Corrales, J. D. (2010). Mamíferos de la Cuenca del Río La Miel (Caldas): Diversidad y Uso Cultural. Boletín Científico. Centro de Museos. Museo de Historia Natural, 14(1), 56-75. Retrieved from http://boletincientifico.ucaldas.edu.co/downloads/Boletin14(1)_4.pdf

Costa-Braga, D., Rossi, J. L., \& Srbek-Araujo, A. C. (2019). Exotic species as the main prey items of the Neotropical otter in the Atlantic Forest, southeastern Brazil. Tropical Ecology, 60(1), 30-40. doi:10.1007/ s42965-019-00004-5

Delibes-Mateos, M., Díaz-Ruiz, F., Caro, J., \& Ferreras, P. (2014). Caracterización de la comunidad de mamíferos de un área remota del sur de Chile mediante el uso combinado de metodologías. Galemys, 26, 65-75. doi:10.7325/Galemys.2014.A7

ESRI. (2018). ArcGIS Pro (Version 10.7). Esri Inc. Retrieved from https://www.esri.com/en-us/arcgis/ products/arcgis-pro/

Foster-Turley, P., Macdonald, S., \& Mason, C. (Eds.). (1990). Otters: an action plan for their conservation. 
Gland, Switzerland: IUCN/SSC Action Plans for the Conservation of Biological Diversity.

Franco, M., Guevara, G., Correa, L., \& Soto-Gamboa, M. (2013). Trophic interactions of the endangered Southern river otter (Lontra provocax) in a Chilean Ramsar wetland inferred from prey sampling, fecal analysis, and stable isotopes. Naturwissenschaften, 100(4), 299-310. doi:10.1007/s00114-013-1027-4

Gomez, J. J., Túnez, J. I., Fracassi, N., \& Cassini, M. H. (2014). Habitat suitability and anthropogenic correlates of Neotropical river otter (Lontra longicaudis) distribution. Journal of Mammalogy, 95(4), 824-833. doi:10.1644/13-mamm-a-265

González-Maya, J. F., Cepeda, A. A., Belant, J. L., ZárrateCharry, D. A., Balaguera-Reina, S. A., \& RodríguezBolaños, A. (2011). Research priorities for the small carnivores of Colombia. Small Carnivore Conservation, 44, 7-13. Retrieved from http://www.smallcarnivoreconservation.org/issue- $44 . \mathrm{html}$

Grajales-García, D., Serrano, A., Capistrán-Barradas, A., Naval-Ávila, C., Pech-Canché, J. M., \& BecerrilGómez, C. (2019). Hábitos alimenticios de la nutria neotropical (Lontra longicaudis annectens) (Carnivora: Mustelidae) en la zona costera de Tuxpan, Veracruz. Revista mexicana de Biodiversidad, 90, e902502. doi:10.22201/ib.20078706e.2019.90.2502

Groenendijk, J., Hajek, F., Duplaix, N., Reuther, C., Damme, P., Schenck, C., . . B Botello, J. C. (2005). Surveying and Monitoring Distribution and Population Trends of the Giant Otter (Pteronura brasiliensis): Guidelines for a Standardisation of Survey Methods as recommended by the Giant Otter Section of the IUCN/SSC Otter Specialist Group.

Hernández-Romero, P. C., Botello López, F. J., Hernández García, N., \& Espinoza Rodríguez, J. (2018). New altitudinal record of Neotropical otter (Lontra longicaudis Olfers, 1818) and conflict with fish farmers in Mexico. IUCN Otter Specialist Group Bulletin, 35(4), 193-197. Retrieved from https://www.iucnosgbull. org/Volume35/Hernandes_Romero_et_al_2018.pdf

IHA. (2019). International Hydropower Association. 2019 Hydropower Status Report: sector trends and insights. International Hydropower Association Limited. Retrieved from https://www.hydropower.org/ download/file/nojs/21571

Juarez-Sanchez, D., Blake, J. G., \& Hellgren, E. C. (2019). Variation in Neotropical river otter (Lontra longicaudis) diet: Effects of an invasive prey species. PLOS ONE, 14(10), e0217727. doi:10.1371/journal. pone. 0217727

Kasper, C. B., Bastazini, V. A. G., Salvi, J., \& Grillo, H. C. Z. (2008). Trophic ecology and the use of shelters and latrines by the Neotropical otter (Lontra longicaudis) in the Taquari Valley, Southern
Brazil. Iheringia. Série Zoologia, 98(4), 469-474. doi:10.1590/S0073-47212008000400009

Kruuk, H. (2006). Otters: ecology, behaviour and conservation. Oxford, U. K.: Oxford University Press.

Larivière, S. (1999). Lontra longicaudis. Mammalian Species(609), 1-5. doi:10.2307/3504393

López-Casas, S., Jiménez-Segura, L. F., \& Pérez-Gallego, C. M. (2014). Peces migratorios al interior de una central hidroeléctrica: caso Miel I, cuenca del río Magdalena (Caldas-Antioquia), Colombia. Biota Colombiana, 15(2), 26-39. Retrieved from http:// revistas.humboldt.org.co/index.php/biota/article/ view/318

Medina-Vogel, G., \& Gonzalez-Lagos, C. (2008). Habitat use and diet of endangered southern river otter Lontra provocax in a predominantly palustrine wetland in Chile. Wildlife Biology, 14(2), 211-220, 210. doi:10.2981/0909-6396(2008)14[211:HUADOE]2.0 . $\mathrm{CO} ; 2$

Navarro-Picado, J., Spínola-Parallada, M., Madrigal-Mora, A., \& Fonseca-Sánchez, A. (2017). Selección de hábitat de Lontra longicaudis (Carnivora, Mustelidae) bajo la influencia de la represa hidroeléctrica del río Peñas Blancas y sus tributarios, Alajuela, Costa Rica. Uniciencia, 31(1), 73-84. doi:10.15359/ru.31-1

Nelson, T. A., \& Boots, B. (2008). Detecting spatial hot spots in landscape ecology. Ecography, 31(5), 556566. doi:10.1111/j.0906-7590.2008.05548.x

Palmeirim, A. F., Peres, C. A., \& Rosas, F. C. W. (2014). Giant otter population responses to habitat expansion and degradation induced by a mega hydroelectric dam. Biological Conservation, 174, 30-38. doi:10.1016/j.biocon.2014.03.015

Pedroso, N. M., Marques, T. A., \& Santos-Reis, M. (2014). The response of otters to environmental changes imposed by the construction of large dams. Aquatic Conservation: Marine and Freshwater Ecosystems, 24(1), 66-80. doi:10.1002/aqc.2379

Pinillosa, L., Pérez-Torres, J., \& Botero-Botero, A. (2018). Diet of Lontra longicaudis in Espejo River, Quindío, Colombia. IUCN Otter Specialist Group Bulletin, 35(4), 222-229. Retrieved from https://www.iucnosgbull.org/Volume35/Pinillosa_et_al_2018.pdf

Quadros, J. (2012). Uso do habitat e estimativa populacional de lontras antes e depois da formação do reservatório de Salto Caxias, rio Iguaçu, Paraná, Brasil. Neotropical Biology and Conservation, 7(2), 97-107. doi:10.4013/nbc.2012.72.03

Restrepo, C. A., Botero-Botero, Á., Puerta Parra, J. C., Franco Pérez, L. M., \& Guevara, G. (2018). El caso de la nutria neotropical (Lontra longicaudis Olfers, 1818) como mascota en el río Magdalena (Colombia). Boletín Científico. Centro de Museos. Museo 
de Historia Natural, 22(2), 76-83. doi:10.17151/ bccm.2018.22.2.6

Reuther, C., Dolch, D., Green, R., Jahrl, J., Jefferies, D., Krekemeyer, A., . . . Trindade, A. (2000). Surveying and monitoring distribution and population trends of the Eurasian otter (Lutra lutra): guidelines and evaluation of the standard method for surveys as recommended by the European section of the IUCN/ SSC Otter Specialist Group (Vol. 12): GN-Gruppe Naturschutz Gmbh.

Rheingantz, M. L., Waldemarin, H. F., Rodrigues, L., \& Moulton, T. P. (2011). Seasonal and spatial differences in feeding habits of the Neotropical otter Lontra longicaudis (Carnivora: Mustelidae) in a coastal catchment of southeastern Brazil. Zoologia (Curitiba), 28(1), 37-44. doi: 10.1590/S1984-46702011000100006

Rheingantz, M. L., de Menezes, J. F. S., \& de Thoisy, B. (2014). Defining Neotropical Otter Lontra Longicaudis Distribution, Conservation Priorities and Ecological Frontiers. Tropical Conservation Science, 7(2), 214-229. doi:10.1177/194008291400700204

Rheingantz, M. L., Santiago-Plata, V. M., \& Trinca, C. S. (2017). The Neotropical otter Lontra longicaudis: a comprehensive update on the current knowledge and conservation status of this semiaquatic carnivore. Mammal Review, 47(4), 291-305. doi:10.1111/ mam. 12098

Rheingantz, M. L., Valenzuela, A., Botero-Botero, A., Thoisy, B. d., Trujillo, F., González, I., . . . Utreras Bucheli, V. M. (2018). Lontra longicaudis. In N. Duplaix \& M. Savage (Eds.), Global Otter Conservation Strategy (pp. 81-89). Salem, Oregon, USA: IUCN Otter Specialist Group.
Riesco, M., Delibes, M., Calzada, J., Esquivias, J., Qninba, A., \& Clavero, M. (2020). Desert otters: Distribution, habitat use and feeding ecology in arid rivers of Morocco. Journal of Arid Environments, 178, 104165. doi:10.1016/j.jaridenv.2020.104165

Rodríguez, N., Armenteras, D., Morales, M., \& Romero, M. (2006). Ecosistemas de los Andes Colombianos (2da. ed.). Bogotá, D. C.: Instituto de Investigación de Recursos Biológicos Alexander Von Humboldt.

Rojas-Morales, J. A., Marín-Martínez, M., \& ZuluagaIsaza, J. C. (2018). Aspectos taxonómicos y ecogeográficos de algunas serpientes (Reptilia: Colubridae) del área de influencia de la Central Hidroeléctrica Miel I, Caldas, Colombia. Biota Colombiana, 19(2), 73-91. doi:10.21068/c2018.v19n02a07

Santos, L. B., \& Reis, N. R. d. (2012). Use of shelters and marking sites by Lontra longicaudis (Olfers, 1818) in lotic and semilotic environments. Biota Neotropica, 12(1), 199-205. doi:10.1590/ S1676-06032012000100016

Somers, M. J., \& Nel, J. A. J. (2004). Movement patterns and home range of Cape clawless otters (Aonyx capensis), affected by high food density patches. Journal of Zoology, 262(1), 91-98. doi:10.1017/ S095283690300445X

Trujillo, F., Caicedo-Herrera, D., Mosquera-Guerra, F., \& Botero-Botero, Á. (2016). Plan de manejo para la conservación de las nutrias (Lontra longicaudis y Pteronura brasiliensis) en Colombia. Bogotá, D. C.: Ministerio de Ambiente y Desarrollo Sostenible, Dirección de Bosques, Biodiversidad y Servicios Ecosistémicos. Fundación Omacha. Retrieved from https://n9.cl/8t510 